\title{
FORAGING ON SOME NONFLORAL RESOURCES BY STINGLESS BEES (HYMENOPTERA, MELIPONINI) IN A CAATINGA REGION
}

\author{
LORENZON, M. C. A. ${ }^{1}$ and MATRANGOLO, C. A. R. ${ }^{2}$ \\ ${ }^{1}$ Instituto de Zootecnia/DRAA, UFRRJ, BR 465, km 7, CEP 23890-000, Seropédica, RJ, Brazil \\ ${ }^{2}$ CCET/Departamento de Agronomia, UNIMONTE, CEP 39499-000, Janaúba, MG, Brazil \\ Correspondence to: Maria Cristina Affonso Lorenzon, Rua Senador Vergueiro, 93/810, \\ Flamengo, CEP 22221-000, Rio de Janeiro, RJ, Brazil, e-mail: lorenzon@sky.com.br \\ Received August 13, 2002 - Accepted January 6, 2004 - Distributed May 31, 2005
}

(With 2 figures)

\begin{abstract}
In a caatinga region the flowers and nonfloral resources visited by highly eusocial bees, stingless beess and Apis mellifera (Africanized honey bee) were studied. During one year, monthly sampling took place in two sites at Serra da Capivara National Park (Piauí State, Brazil), one of them, including the local village, outside the park, and the other inside, using already existing park trails. With the help of entomological nets, all bees were caught while visiting floral and nonfloral resources. At the study sites we observed more stingless bees in nonfloral resources, made possible by human presence. Twelve stingless bee species used the nonfloral resources in different proportions, showing no preference for time of day, season of the year, or sites. During the rainy season, more water sources and abundant flowering plants were observed, which attract stingless bees, even though many worker bees were found foraging in the aqueous substrates while few were observed at water sources. This relationship was higher for stingless bee species than for Africanized honey bees. Paratrigona lineata was represented by few specimens in floral and nonfloral resources and is perhaps rare in this region. Frieseomelitta silvestrii could be considered rare in the floral resources, but they were abundant in nonfloral resources. The variety and intriguing abundance of bees in nonfloral resources suggests that these are an important part of the stingless bee niches, even if these resources are used for nest construction and defense.
\end{abstract}

Key words: eusocial bee, detritus, semi-arid region, food resources.

\section{RESUMO}

Forrageamento em alguns recursos não florais pelas abelhas sem ferrão (Hymenoptera, Meliponini) em região de caatinga

Na região de caatinga, verificou-se a visita de meliponíneos e Apis mellifera (abelhas Africanizadas) aos recursos não florais e às fontes florais. Durante um ano foram realizadas amostragens mensais em dois locais do Parque Nacional da Serra da Capivara, Piauí, Brasil: partes externa, que inclui parte do vilarejo, e interna, em algumas trilhas existentes no Parque. As abelhas foram capturadas quando visitavam as plantas em flores e em outros recursos não florais, utilizando-se redes entomológicas. A fauna de meliponíneos na Serra da Capivara, pertencente a 12 espécies, foi mais abundante e generalizada entre os diferentes recursos não florais, cuja ocorrência foi favorecida pela presença do homem. Verificouse que as variações da coleta dos recursos não florais pelas abelhas ao longo do dia, nas estações do ano e nos locais de estudo, não foram significativas. Aparentemente, na estação chuvosa houve grande número de floradas atrativas aos meliponíneos e maior disponibilidade de fontes de água, mesmo assim observouse expressivo número de indivíduos nos recursos não florais, particularmente nos substratos aquosos, e poucas abelhas coletando nas fontes de água: para os meliponíneos essa relação foi bem maior comparada à das Africanizadas. Paratrigona lineata foi representada por poucos indivíduos, podendo ser considerada rara na região. Frieseomelitta silvestrii poderia ser distinta também como rara nos recursos florais, porém foi abundante nos não florais. Essa variedade e intrigante abundância de abelhas nos recursos não florais 
sugere ser parte importante do nicho dos meliponíneos, mesmo que sejam utilizados como material de construção e defesa do ninho.

Palavras-chave: abelhas eussociais, detritos, região semi-árida, fontes de recursos.

\section{INTRODUCTION}

The meliponines are a pantropical group with at least 400 species described (Kerr, 1969; Michener, 1974; Wille, 1979; Michener, 2000). These bees lack a functional sting, are eusocial, and live in perennial colonies. Most stingless bees colonies present a smaller number of foragers than Apis mellifera, however they are able to forage in a broader range of food plants, which allows storage of a large amount of food in their nests (Schwarz, 1948; Wille, 1983; Roubik, 1983).

The kind of food that the major stingless bee species harvest is nectar and pollen and, in their colonies, separate stocking of these supplies in pots is quite perceptible. Besides these main provisions obtained from flowers, stingless bees display an immense diversity in resource use, which includes sap, feces, carrion, urine, oils, resins, bark, gums, fruit juice, leaves, trichomes, mud, salt solutions, water, gravel, etc., as well as gathering honeydew excreted by plant-feeding homopterans (Roubik, 1989). Their menu (Schwarz, 1948; Kerr, 1969; Michener, 1974; Roubik, 1989) is thus much more diverse than that of Apis mellifera.

Commonly, excrement is used by stingless bees to build their nests, which are then waterproof and highly resistant to attack by predators (NogueiraNeto, 1970; Baumgartner \& Roubik, 1989; Ramalho et al., 1991). Wille \& Michener (1973) noticed the presence of excrement on the outside of exposed stingless bee nests. In addition, excrement can also be a source of nitrogen and minerals, or function as a germicide in bee colonies (Roubik, 1989). Baumgartner \& Roubik (1989) suggested that certain bee species supplement their ordinary pollen and nectar diet with animal products. Included among these species is Apis mellifera, observed collecting in human excrement by Sackett (1919). But no proof exists that fecal matter is used exclusively as nesting material (Roubik, 1989), nor that it can be a source of nitrogen or phosphates, thereby functioning as a nutritional supplement. Nogueira-Neto (1997) has observed human and vertebrate excrement being gathered by Melipona quadrisfaciata, Schwarziana quadripunctata, Trigona spinipes, T. recursa, and
$M$. rufiventris to build a strongly scented separation wall, called batumen, in their hives.

Dead animal flesh is used instead of other protein sources by certain bee species, and necrophagy can be facultative or obligate (Roubik, 1982). According to Noll et al. (1996), the Trigona hypogea group is remarkable for its obligate necrophagy, having replaced pollen by animal flesh as a protein source (Camargo \& Roubik, 1991; Noll et al., 1996). In addition, necrophagous habits are closely related to a group of Trigona, which differ significantly from all other Trigona in possessing large teeth on each mandible (Roubik, 1982). Other necrophagous taxa are T. necrophaga from Panama and Costa Rica and T. crassipes from Amazon are (Roubik, 1982; Gilliam et al., 1985; Roubik et al., 1995). Furthermore, facultative necrophagy can characterize more species, as reported by Cornaby (1974) who observed a dead lizard being foraged by seven species of stingless bees of a large arthropod taxa. These carrion feeders can find dead animals quickly, especially during the dry season (Cornaby, 1974; Crewe, 1985).

Necrophagous foragers can be observed biting off, masticating, and consuming large pieces of flesh (Roubik, 1982), or a mix of substances (Crewe, 1985). In the hot and extremely dry weather of a location in Africa, Crewe (1985) observed Trigona gribodoi and Apis mellifera scutellata foraging in a dead animal and appearing to be collecting moisture from its surface, which was then transported by mouth by the foraging worker bees.

According to Roubik (1983) and Gilliam et al. (1985), in necrophagous colonies, larval cell provisions, which present nutrient levels very similar to those found in Apis royal jelly, are used as though they were pollen. At first, this stored substance is paste-like and retains the color of the source from which it was collected; after maturation, it becomes a viscous fluid, homogenous and yellowish, composed of sugars and free amino acids (Noll et al., 1996). Cruz-Landim \& Serrão (1994) considered the animal protein used by these bee species advantageous because it is more easily digested and leaves less fecal residue than pollen.

A search for sweat has been observed among stingless bees, honey bees, and halictid bees (Schwarz, 
1948; Michener, 1974). The habit of licking sweat was observed in Apis mellifera (Katzenelson, 1969) and in Plebeia sp. (Nogueira-Neto, 1997). According to Bertsch (1984), eventually the bees accumulate excess metabolic water, which may lead to excretion rates that accelerate a loss of ions that must be replenished. Sodium salts, potassium, and phosphates are in great demand among bees, and can be found in resources such as urine, feces, blood, washed clothes, and ashes. The gathering of these organic salts and other unusual substances proves that we still have little knowledge about food sources and their nutritional value.

The detritus food chain is one of the major pathways for the nutrient movement in tropical ecosystems (Odum \& de la Cruz, 1963; Wiegert \& Owen, 1971). Therefore, it must be emphasized that detritus can play a key role in the study of the relationship between bees and nonfloral resources, and can provide valuable insight into the functioning of tropical ecosystems. Thus, the comprehension of bee ecology requires knowledge of the various resources they use whether in maintaining their metabolism, or in defending and building their nests. With respect to stingless bees, this kind of knowledge is still incomplete.

This paper is intended to provide more detailed information on exploitation by highly eusocial bees of nonfloral resources, including those provided by a human community close to a conservation region.

\section{MATERIAL AND METHODS}

This study was conducted at Serra da Capivara National Park (08²6'50'S and $42^{\circ} 45^{\prime}$ '51'W) in a tropical dry lowland, southeast of Piauí State, Brazil. Serra da Capivara lies in a caatinga morphclimatic domain. The study place has primary caatinga vegetation and some patches of transition area, included an area measuring 129,140 ha. The climate is at the limit between arid and semi-arid, hot and dry, with an annual average temperature of $28^{\circ} \mathrm{C}$, with rain totaling approximately $689 \mathrm{~mm}$ per year. There are two seasons: rainy (from October to May) and dry (from May to September).

Observations took place in two sites, both of which were divided into three arbitrarily established transects each, according to Sakagami et al. (1967). All six transects measured $400 \mathrm{~m} \times 8 \mathrm{~m}$, representing $9,600 \mathrm{~m}^{2}$ of sampled area. The first of the sites, both of which were chosen due to easy access to already existent trails, was located outside the park entrance and included three residences and a camping area. Site 2, located more than $2 \mathrm{~km}$ from the village, was inside the park (Fig. 1). On either site, there were many large containers (caldeirões) used to provide water to animals throughout the year.

Near site 1, many Africanized honey bees apiaries were observed. A few people from the village kept stingless bees in boxes or felled tree trunks, but many said that they themselves collected honey directly from the local stingless bee colonies.

The survey started in June 1998 and ended in July 1999, with one sampling period per month; the first two months were dedicated to assays. The sampling activities were performed in two days per transect, per site, and an annual schedule was elaborated. Two researchers went through the trails to sample bees from 0600 AM to 0600 PM per collection day. Field collections were made in such a way as to observe each transect at different times, until 12 observation hours were completed. Sampling was taken when highly eusocial bees were found at the floral and nonfloral resources, and noting particularly with as much accuracy as possible, the overall abundance. Bee presence in organic detritus was also record by the observers throughout the entirety of the sampling. Because of the random distribution of floral and nonfloral resources, a standardized sampling procedure could not be carried out.

All bee individuals were caught, with the use of entomological nets, while they were visiting food resources, biting off fruit, or collecting water, resins, feces, sweat, urine, whether near or far from the houses and also during flight. Soon after the capture, all bees were counted. Limited voucher specimens of each recognized morph-species associated with a particular kind of resource were collected. They were killed with ethyl acetate in individual flasks, pricked, and labeled and registered by the popular name of the plant or other substrates, the date, collection schedule, and the abundance of bees visiting the floral or nonfloral resources under observation.

Here we report on only highly eusocial bees. The abundance of these bee species was organized according to study site, floral or nonfloral resource in which found, time of day, season of year, and bee species. The t-test was used for statistical comparisons of the bee visitation in nonfloral resources by study site (1 and 2), time of day (morning or afternoon) and season of year (dry and rainy). 


\section{RESULTS}

Nonfloral resources visited by the bees at Serra da Capivara Park were: site 1 (outside park) - flesh, water, water + food remains, salts, sweat, urine, food remains; site 2 (inside park) - honeydew, seeds, resins, urine, water, and rotten fruit. A total of 2875 individuals were netted at floral and nonfloral resources, 127 of which were Africanized honey bees; 12 species of stingless bees were among the 1018 specimens captured in nonfloral resources (Table 1).

Our sample comprised the following stingless bee species: Melipona asilvae Moure 1971; M. quinquefasciata Lepetelier 1836; Trigonisca sp., Plebeia flavocincta Cokerell 1912 auctorum; Frieseomelitta silvestrii Friese 1902; F. flavicornis Fabricius 1798 auctorum; Partamona sp., Paratrigona lineata Lepetelier 1836; Trigona sp. (*), T. spinipes Fabricius 1793; T. recursa Smith 1863; Carmagoia nordestina Camargo 1996.

Table 1 presents the abundance of Africanized honey bees and the species composition of stingless bees collected in floral and nonfloral resources in Serra da Capivara. Most of the stingless bee species presented a higher number of individuals in nonfloral resources nearby human settlements, in which such resources were easily found. In numbers, this means the perceptual factor is $4 \%$ bigger in nonfloral resources as compared to the floral ones. All the stingless bee species were collected in more than one nonfloral resource and their abundance in each subtract was variable. Even Apis mellifera was captured in flesh and urine. As for the oil-producing Malpighiaceae species (Sazima \& Sazima, 1988; Roubik, 1989; Rego \& Albuquerque, 1989), Cardiopermum corindum, Byrsonima sp., which of these were gathered by $T$. spinipes, $P$. flavocincta, Trigonisca sp., Partamona sp., and the rarely encountered Apis mellifera hcould not be distinguished. The major nonfloral resources of exploited by the stingless bees were aqueous subtracts (sites 1 and 2), which had a search rate $126 \%$ bigger than that for the dry resources. Gathering at liquid substrates by the bees fell drastically soon after the daily rain stopped.

With natural depressions in the rocks (boqueirões), dams, and brooks full of water during the rainy season, the aqueous substrate foragers rose by $100 \%$ compared to the rate in the dry season.
However, little water collecting by Apis mellifera was observed at the caldeirões. No stingless bees were found during the rainy season but many of them, as well as Apis, were observed during the dry season.

The people living near Serra da Capivara Park told us that stingless bees are known for disturbing people having sweat on their face or arms. During the observations, a count was kept of the number of bees collecting sweat from the observers themselves, as they walked along the trails in both sites. Sweat-gathering was higher in the $P$. flavocincta and Trigonisca sp., although this was also seen sporadically in $M$. quinquefasciata, $C$. nordestina, $T$. recursa, $F$. silvestrii, and $P$. lineata.

T. spinipes workers were observed collecting resin while Trigona sp. was observed collecting honeydew in both sites. Close to the village and in the camp site (site 1), a high number of bees were observed visiting salted cattle meat (carne de sol) (Fig. 2). The stingless bees, and sometimes Apis mellifera workers, appeared to be gathering salt or moisture. Closer inspection revealed that they were licking with tongues everted; nothing was stored in their corbiculae.

The study year was considered good for agriculture by the meteorological service and local residents. Thus, during ten months eusocial bees were observed foraging on flowering plants in abundance and on nonfloral resources throughout the year. The rainy season concentrated $84 \%$ of the 68 flowering plant species collected all year. The blooming periods for most flowering species lasted for more than three months. During the end of the dry season, from August to September, when there were still a few flowers in the field, the great majority of stingless bees (38) were captured on nonfloral resources. Another two were on floral ones. The Africanized honeybee was not captured on any resources during the end of the dry season and the beginning of the rainy season. $F$. silvestrii was very much more easy to find in nonfloral resources than in floral ones, whereas $P$. lineata was represented by only a few specimens in both resources.

Table 2 presents abundances of stingless bees and Africanized honey bees that were collected in floral and nonfloral resources at the two studies sites of Serra da Capivara, during both dry and rainy seasons in both morning and afternoon periods.

(*) Regionally they are called vamos embora. 
TABLE 1

Abundance of the Africanized honey bees (Apis mellifera) and stingless bees (Meliponini) in floral and nonfloral resources collected in "caatinga" region. at Serra da Capivara National Park, Piauí State. 1998/1999.

\begin{tabular}{|c|c|c|c|c|c|c|c|c|c|c|c|c|c|c|}
\hline \multirow{2}{*}{ Resources } & \multicolumn{14}{|c|}{$\begin{array}{l}\text { Eusocial bee species } \\
\text { Stingless bees }\end{array}$} \\
\hline & Am & $\mathrm{Ma}$ & $\mathrm{Mq}$ & $\mathrm{Cn}$ & Pf & Fs & $\mathrm{Ff}$ & Par & $\mathrm{Pl}$ & $\mathrm{T}$ & Ts & $\operatorname{Tr}$ & $\mathrm{Tg}$ & Mel \\
\hline \multicolumn{15}{|c|}{ In nonfloral resources (sites 1 and 2 ) } \\
\hline Water & 20 & 0 & 0 & 0 & 19 & 0 & 0 & 7 & 5 & 0 & 0 & 0 & 19 & 50 \\
\hline Honeydew & 0 & 0 & 0 & 0 & 51 & 0 & 17 & 0 & 0 & 0 & 0 & 0 & 0 & 50 \\
\hline Seed & 0 & 0 & 0 & 0 & 1 & 0 & 0 & 0 & 0 & 0 & 0 & 0 & 0 & 68 \\
\hline Rotten fruit & 0 & 0 & 0 & 0 & 0 & 0 & 9 & 0 & 0 & 0 & 0 & 0 & 0 & 1 \\
\hline Resin & 0 & 1 & 0 & 0 & 3 & 0 & 0 & 2 & 0 & 0 & 0 & 0 & 0 & 9 \\
\hline \multicolumn{15}{|c|}{ In nonfloral resources near houses, camp site (site 1) } \\
\hline $\begin{array}{c}\text { Water + } \\
\text { substract }\end{array}$ & 25 & 12 & 2 & 0 & 70 & 0 & 0 & 18 & 0 & 17 & 0 & 0 & 13 & 132 \\
\hline Urine & 62 & 15 & 1 & 3 & 0 & 0 & 0 & 32 & 0 & 17 & 0 & 0 & 14 & 82 \\
\hline Flesh & 6 & 15 & 8 & 10 & 76 & 32 & 0 & 25 & 1 & 15 & 26 & 0 & 3 & 211 \\
\hline Food & 0 & 0 & 0 & 0 & 17 & 0 & 0 & 0 & 0 & 0 & 0 & 0 & 0 & 17 \\
\hline Salts & 9 & 0 & 0 & 0 & 6 & 0 & 0 & 8 & 0 & 4 & 0 & 0 & 6 & 24 \\
\hline \multicolumn{15}{|c|}{ From the researchers (sites 1 and 2) } \\
\hline Sweat & 5 & 32 & 8 & 2 & 0 & 0 & 0 & 10 & 8 & 217 & 137 & 4 & 0 & 418 \\
\hline \multicolumn{15}{|c|}{ Nonfloral resources } \\
\hline Subtotals & 127 & 75 & 19 & 15 & 243 & 32 & 26 & 102 & 14 & 270 & 163 & 4 & 55 & 1018 \\
\hline \multicolumn{15}{|c|}{ In flowering plants } \\
\hline $\begin{array}{c}\text { Flowers } \\
\text { totals }\end{array}$ & 752 & 12 & 9 & 30 & 52 & 3 & 11 & 342 & 4 & 14 & 241 & 217 & 43 & 978 \\
\hline \multicolumn{15}{|c|}{ Floral + nonfloral resources } \\
\hline Totals & 879 & 87 & 28 & 45 & 295 & 35 & 37 & 444 & 18 & 284 & 567 & 221 & 98 & 1996 \\
\hline
\end{tabular}

Am (Apis mellifera), Mel (Meliponini species), Ma (Melipona asilvae), Mq (M. quinquefasciata), Cn (Carmagoia nordestina), Pf (Plebeia flavocincta), Fs (Frieseomelitta silvestrii), Ff (F. flavicornis), Par (Partamona sp.), Pl (Paratrigona lineata), T (Trigona sp.), Ts (Trigona spinipes), Tr (T. recursa), Tg (Trigonisca sp.).

The comparisons done with the t-test for nonfloral resources resulted in non-significant differences $(p=0.05)$ between sites, between morning and afternoon periods, and between dry and rainy seasons (Table 2).

\section{DISCUSSION}

A higher number of stingless bee specimens were generally captured in nonfloral resources, including Apis mellifera. Eight of the 12 stingless bee species captured abounded in nonfloral resources but not in floral ones (Table 1). Forager bees preferred nonfloral resources, no matter the study site, season, or time of day, indicating the importance of this type of resource to stingless bees, which they preferred even when flower resources were abundant. However, it must be stress that, in comparison with floral resources, nonfloral ones are much more ephemeral and occasional, features that could explain the fast 
foraging and recruitment of forager bees to exploit these resources when available, which makes it seem probable that. Some of these resources could be used as traps to capture these species. Interestingly enough, research carried out by Martins (1994), Aguiar \& Martins (1997), and Viana (1999) that took place in caatinga regions did not include any observations about bee foraging on nonfloral resources.

Viana (1999) and Martins (1990) designated a bee species as rare when a diminished number of bee specimens (one or two individuals) were collected. While $F$. silvestrii in floral resources of Serra da Capivara can be considered rare, the same is not true for nonfloral resources (Table 1). Only P. lineata could really be designated as rare, since only two individuals were found at floral and nonfloral resources. (A bee species can only be considered rare if all its possible resources have been investigated.)

It must be emphasized that caatinga vegetation is not poor in floral resources and plants therein are adapted to water stress. Thus, the high number of stingless bees in nonfloral resources does not imply nutritional compensation. Since the rainy season provided abundant floral resources, perhaps the nonfloral resources exploited by these bees were being used for protection against natural enemies or construction of new nests, etc., both of which are important niche dimensions to bee colony survival.
With respect to abundance of stingless bee workers on aqueous substrates under semi-arid conditions, they can be expected to gather moisture in the most diverse ways. But in the rainy season, the search for aqueous nonfloral resources was higher than it was for water sources, indicating that this kind of resource is attractive to bees for reasons beyond water gathering.

The large occurrence of stingless bees on sweat and jerked beef (Fig. 2) might be connected to the bees' need for mineral salts. Bertsch (1984) has reported that bees seek out mineral salts to replace lost ions in resources such as urine, feces, and sweat. Information about the nutritional value of salts to bees is still incomplete. Flesh, dried orflesh blood, urine, and food remains, which provide sources of nitrogen, can also be supplements to pollen diets (Roubik, 1989). In addition, these resources may be used for defense purposes, as building materials for the nests, or making them better able to withstand attacks from predators (Ramalho et al., 1991).

During the dry season when floral resources are rarely found, these kinds of resource could be used as food sources by the bees to compensate for lack of nitrogen. (To the Africanized honey bees, this type of resource is apparently of little dietary importance, since the species was not captured at all during four months of the dry season.)

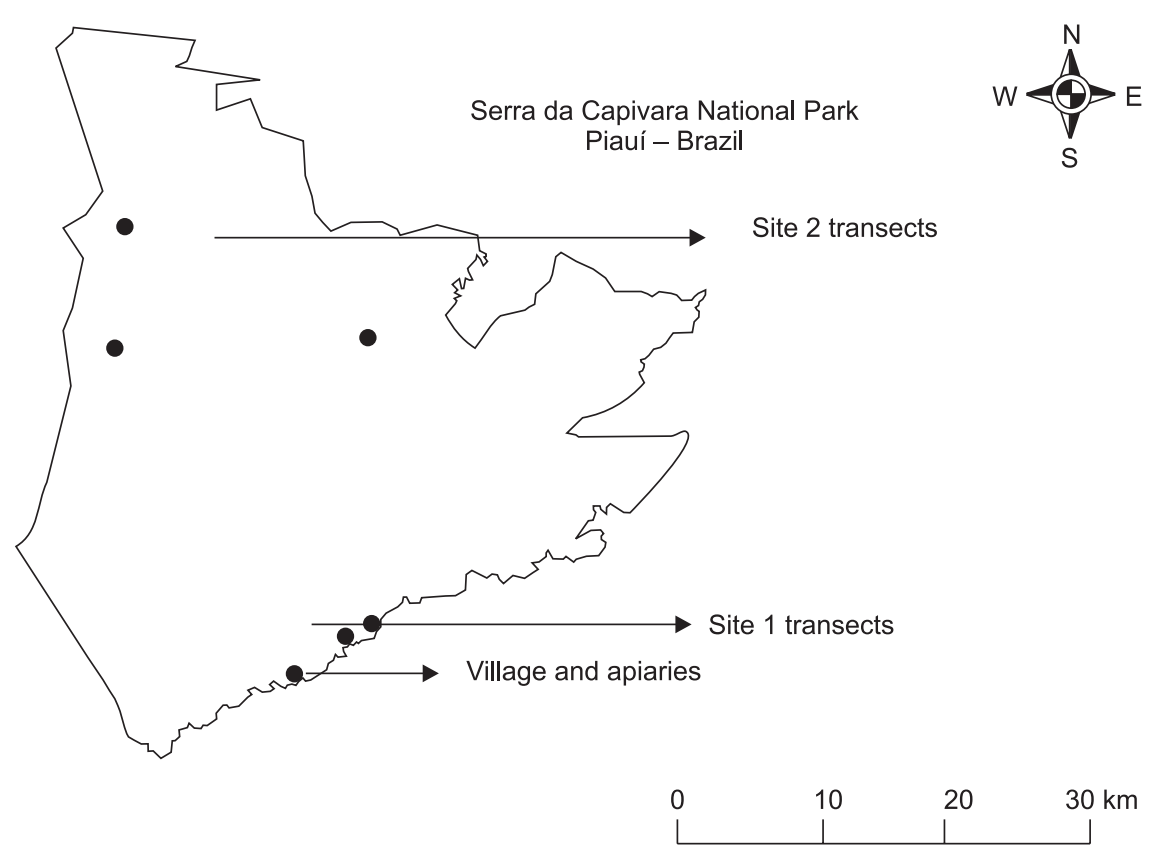

Fig. 1 - Serra da Capivara National Park map and study site locations, the transects, the village, and apiaries. 
TABLE 2

Africanized honey bees and stingless bee abundance in floral and nonfloral resources considering the study sites, diary schedule, and season of the year in the caatinga region. Serra da Capivara National Park, Piauí State. 1998/1999.

\begin{tabular}{|c|c|c|c|c|c|c|}
\hline \multirow{2}{*}{ Resources } & \multicolumn{2}{|c|}{ Site } & \multicolumn{2}{c|}{ Time } & \multicolumn{2}{c|}{ Season of the year } \\
\cline { 2 - 7 } & 1 & 2 & Morning & Evening & Dry & Rainy \\
\hline Floral & 734 & 996 & 1174 & 556 & 444 & 1286 \\
\hline Nonfloral & $484^{\mathrm{a}}$ & $661^{\mathrm{a}}$ & $475^{\mathrm{b}}$ & $672^{\mathrm{b}}$ & $478^{\mathrm{c}}$ & $667^{\mathrm{c}}$ \\
\hline$t$ value & \multicolumn{2}{|c|}{0,075} & \multicolumn{2}{c|}{0,71} & \multicolumn{2}{c|}{0,74} \\
\hline $\mathrm{p}<0.05$ & \multicolumn{2}{|c|}{ No $(\mathrm{p}=0.79)$} & \multicolumn{2}{c|}{ No $(\mathrm{p}=0.40)$} & \multicolumn{2}{c|}{ No $(\mathrm{p}=0.70)$} \\
\hline
\end{tabular}

Means followed by the same letter in the lines are not significantly different by t-test (5\% level). Small letters a, b, and c show independent t-test among variables (site, time, and season).

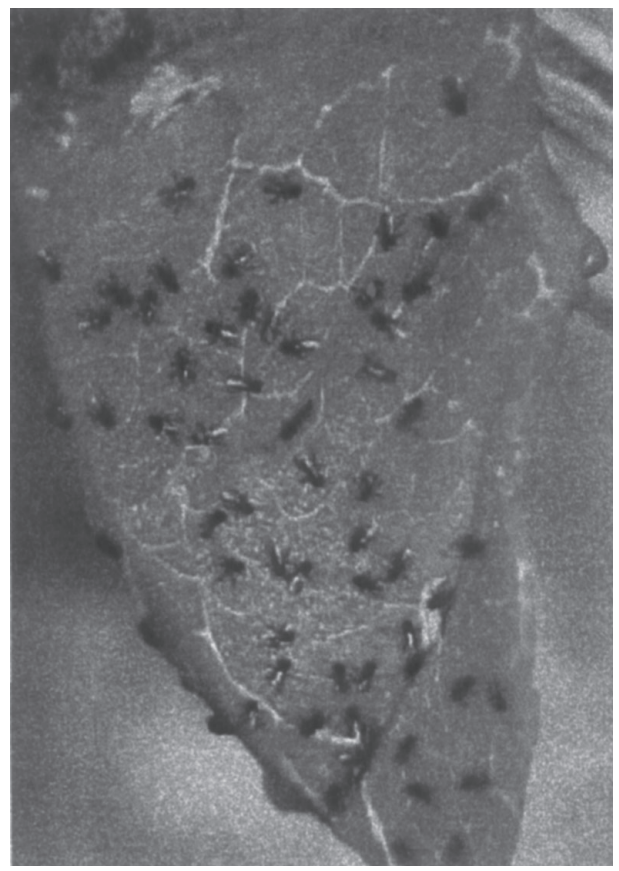

Fig. 2 - Large number of Trigona workers forage on salted cattle meat laid in the sun to dry. Serra da Capivara, Piauí State, Brazil.

This study does not intend to suggest that floral resources partitioning among stingless bees and Africanized honeybees could be due to stingless bees' preference for nonfloral resources. Although local human presence probably increased bee occurrence at nonfloral resources, certainly many other nonfloral resources attractive to bees exist in natural habitats (Odum \& De la Cruz, 1963; Wiegert \& Owen, 1971). Indeed, nonfloral resource dispersion and more rapid transfer in tropical systems can make investigations more difficult, but they should continue in view of the amount and availability of such resources.

Acknowledgements - We are grateful to Fundação do Homem Americano (FUMDHAM) of Parque Nacional da Serra da Capivara for authorizing this research and helping with fieldwork. We also thank Prof. Og F. de Sousa (Universidade Federal de Viçosa) for suggestions helpful in preparing this manuscript. Special thanks go to Sílvia R. de M. Pedro, of the Biology Department, Universidade de São Paulo in Ribeirão Preto, São Paulo State, for identifying stingless bees species. We are also grateful to anonymous reviewers for valuable comments. 


\section{REFERENCES}

AGUIAR, C. M. L. \& MARTINS, C. F., 1997, Abundância relativa, diversidade e fenologia de abelhas (Hymenoptera, Apoidea) na caatinga, São João do Cariri, Paraíba. Iheringia Ser. Zool., 83: 151-163.

BAUMGARTNER, D. \& ROUBIK, D. W., 1989, Ecology of necrophilous and filth-gathering stingless bees (Apidae, Meliponinae). Journal of the Kansas Entomological Society, 62:11-22.

BERTSCH, A., 1984, Foraging in male bumblebees (Bombus lucorum L.): maximizing energy or minimizing water load? Oecologia, 62: 325-336.

CAMARGO, J. M. F. \& ROUBIK, D. W., 1991, Systematics and bionomics of the apoid obligate necrophages: The Trigona hypogea group (Hymenoptera: Apidae, Meliponinae). Linn. Soc., 44: 13-39.

CORNABY, B. W., 1974, Carrion reduction by animals in contrasting tropical habitats. Biotropica, 6(1): 51-63.

CREWE, R. M., 1985, Bees observed foraging on an impala carcass. Bee World, 66: 8.

CRUZ-LANDIM, C. \& SERRÃO, J. E., 1994, The evolutive significance of pollen use as protein resource by Trigonini bees (Hymenoptera, Apidae, Meliponinae). J. Adv. Zool., 15: 15.

GILLIAM, M., BUCHMANN, S. L. \& LORENZ, B. J., 1985, Microbiology of the larval provisions of the stingless bee, Trigona hypogea, an obligate necrophage. Biotropica, 17(1): 28-31.

KATZENELSON, M., 1969, Las abejas africanas en el Norte argentino. Gaceta del Colmenar, 31(6): 182-188.

KERR, W. E., 1969, Some aspects of evolution of social bees. Evolution Biology, 3: 119-175.

MARTINS, C. F., 1990, Estrutura da comunidade de abelhas (Hym., Apoidea) na caatinga (Casa Nova, BA) e na Chapada Diamantina (Lençóis, BA). Tese de Doutorado, Instituto de Biociências, Universidade de São Paulo, 159p.

MARTINS, C. F., 1994, Comunidade de abelhas (Hym., Apoidea) da caatinga e do cerrado com elementos de campo rupestre do Estado da Paraíba. Rev. Nordestina de Biologia, 9(2): 225257.

MICHENER, C. D., 1974, The social behavior of the bees. Bel Knap Press of Harvard University Press, Cambridge, 404p.

MICHENER, C. D., 2000, The bees of the world. The Johns Hopkins Univ., London, 913p.

NOGUEIRA-NETO, P., 1970, A criação de abelhas indígenas sem ferrão. Ed. Tecnapis, São Paulo, 365p.

NOGUEIRA-NETO, P., 1997, Vida e criação das abelhas indígenas sem ferrão. Ed. Nogueirapis, São Paulo, 446p.

NOLL, F. B., ZUCCHI, R., JORGE, J. A. \& MATEUS, S., 1996, Food collection and maturation in the necrophagous stingless bee, Trigona hypogea (Hymenoptera, Meliponinae). Journal of the Kansas Entomological Society, 69(4) suppl.: 287-293.
ODUM, H. T. \& DE LA CRUZ, A. A., 1963, Detritus as a major component of ecosystems. A.I. B.S. Bull., 13: 39-40.

RAMALHO, M., KLEINET-GIOVANNINI, A. \& IMPERATRIZFONSECA, V. L., 1991, Ecologia nutricional das abelhas sociais, pp. 225-242. In: A. R. Panizzi \& J. R. P. Parra (orgs.), Ecologia nutricional de insetos e suas implicações no manejo de pragas. 1. vol. CNPq \& Ed. Manole Ltda., Brasília, 359p.

REGO, M. M. C. \& ALBUQUERQUE, P. M. C., 1989, Comportamento das abelhas visitantes de murici (Byrsonima crassifolia). Boletim do Museu Paraenese Emílio Goeldi, ser Zoológica, 5(2): 179-193.

ROUBIK, D. W., 1982, Obligate necrophagy in a social bee. Science, 217: 1059-1060.

ROUBIK, D. W., 1983, Nest and colony characteristics of stingless bees from Panama (Hymenoptera: Apidae). Journal of the Kansas Entomological Society, 56: 327-355.

ROUBIK, D. W., 1989, Ecology and Natural history of tropical bees. Cambridge, Cambridge University Press, 511p.

ROUBIK, D. W., YANEGA, M., ALUJA, M., BUCHMANN, S. L. \& INOUYE, D. W., 1995, On optimal nectar foraging by some tropical bees (Hymenoptera, Apidae). Apidologie, 26: 197-211.

SACKETT, W. G., 1919, Honey as carrier of intestinal diseases. Exp. Station Colorado Agric. College Bull., 252: 1-18.

SAKAGAMI, S. F., LAROCA, S. \& MOURE, J. S., 1967, Wild bee biocenotics in São José dos Pinhais (Pr), South Brazil. Preliminary report. J. Fac. Sci. Hokkaido Univ., Sapporo., Ser, 6: 57-127.

SAZIMA, M. \& SAZIMA, I., 1988, Oil gathering bees visit flower of eglandular morphs of the oil producing Malpighiaceae. Botânica Acta, 102: 106-11.

SCHWARZ, H. L., 1948, The stingless bees (Meliponini) of the Western Hemisphere. Bull. Am. Mus. Nat. Hist., 90: 1-546.

VIANA, B. F., 1999, A comunidade de abelhas (Hymenoptera: Apoidea) das dunas interiores do Rio São Francisco, Bahia. An. Soc. Entomol. Bras., 28(4): 635-645.

WIEGERT, R. G. \& OWEN, D. F., 1971, Trophic structure, available resources and population density in terrestrial vs aquatic ecosystems. J. Theor. Biol., 30: 69-81.

WILLE, A., 1979, Physiology and relationships among the genera and subgenera of the stingless bees of the world. Rev. Biol. Trop., 27: 241-277.

WILLE, A., 1983, Biology of the stingless bees. Ann. Rev. Entomol., 28: 41-64.

WILLE, A. \& MICHENER, C. D., 1973, The nest architecture of stingless bees with special reference to those of Costa Rica. Rev. Biol. Trop., 12(12): 187-195. 